\title{
Kinetics of microbial mineralization of organic carbon from detrital Skeletonema costatum cells
}

\author{
Robert J. Pett \\ Department of Oceanography, Dalhousie University, Halifax, Nova Scotia, Canada B3H 4J1
}

\begin{abstract}
Long-term $(6 \mathrm{mo})$ studies of the mineralization of detrital ${ }^{14} \mathrm{C}$-labelled Skeletonema costatum cells by coastal microbial communities demonstrated the existence of 4 main pools $\left(G_{1}\right)$ of 'utilizable' organic material. The most labile fraction, $G_{01}$ material, comprised $13 \%$ of the algal biomass and was consumed via first-order kinetics in $14 \mathrm{~h}$. The $\mathrm{G}_{02}, \mathrm{G}_{03}$ and $\mathrm{G}_{04}$ fractions 154,29 and $4 \%$ of the algae respectively) had turnover times on the order of days to weeks, months and years, respectively. Definition of pool size and lability was based on changes in first-order consumption rates of particulate and dissolved organic carbon (POC and DOC) released from intact cells during the experimental period. Sodium azide inhibition of bacterial metabolism resulted in DOC accumulation at rates approximating POC mineralization rates and community metabolism, but problems with incomplete inhibition of the uptake of $G_{01}$ materials negated conclusions concerning natural DOC release rates from algae. Conflicting opinions on the response of benthic communities and deep-water bacterioplankton to sedimenting algal blooms may be resolved through consideration of the amount of $\mathrm{G}_{01}$ and $\mathrm{G}_{02}$-organic matter which remain in detrital algae.
\end{abstract}

\section{INTRODUCTION}

In recent reviews on the fate of organic matter in the sea, Azam and co-workers (Azam \& Ammerman 1984, Azam 1986, Azam \& Cho 1987) suggest there is a tight coupling between the production and the consumption of 'utilizable' dissolved organic matter (DOM) by the bacterioplankton. Most of the original studies summarized in these reviews have concentrated on the fate of labile fractions of algal exudates, or labile substrates such as glucose and glutamate in short-term experiments (times on the order of a day or less). Utilization of the more refractory pools of exudate DOM and of DOM hydrolyzed from detrital particulate organic matter (POM) has not been as rigorously examined. As noted by Biddanda (1988), there is little intrinsic difference in how bacteria respond to POM or DOM; mineralization rates of refractory materials will be a function of the frequency of contact of bacteria and substrate, a necessary requirement for surface-bound exoenzyme hydrolysis (Hollibaugh \& Azam 1983, Rego et al. 1985), and of the speed at which the bacterial assemblage can produce the requisite enzymes.

Laboratory studies of the decay of algae and other POM in water and sediment indicate that POM is composed of at least 2 labile fractions and a non- reactive fraction (Garber 1984, Westrich \& Berner 1984, Henrichs \& Doyle 1986, Grant \& Hargrave 1987). The disappearance of each of the reactive fractions $\left(\mathrm{G}_{i}\right)$ over time can be predicted by first-order reaction kinetics in Berner's (1980) multi-G model:

$$
\frac{\mathrm{dG}_{i}}{\mathrm{dt}}=-\mathrm{k}_{\mathrm{t}} \mathrm{G}_{i}
$$

where $\mathrm{k}_{i}=\mathrm{a}$ first-order decay constant. The total quantity of POM $\left(G_{T}\right)$ at any time is the sum of the exponentially declining fractions $\left(G_{i}\right)$ plus the non-reactive fraction $\left(\mathrm{G}_{\mathrm{NR}}\right)$ :

$$
\mathrm{G}_{\mathrm{T}}(t)=\Sigma \mathrm{G}_{i} \exp \left(-\mathrm{k}_{1} t\right)+\mathrm{G}_{\mathrm{NR}}
$$

For microbial-mediated decay of POM to occur, bacteria must first solubilize each of the fractions into DOM, or await passive leakage of intracellular DOM across cell membranes (Bjørnsen 1988). The few studies of POM decay which have considered DOM cycling note that production and consumption were closely matched resulting in little loss of DOM to the external environment (Kepkay \& Andersen 1985, Schwinghamer \& Kepkay 1987). However, these studies were concerned with the fate of Spartina litter buried in sediments, an environment with signficantly slower rates of diffusion and material transport than the 
water column. Newell et al. (1981) and Biddanda (1988) considered the short-term fates of both POM and DOM in seawater samples, but unfortunately used phytoplankton debris, consisting of cells exploded by osmotic shock or freeze-heat cycles, rather than intact cells.

If bacterial metabolism is limited by DOM quality and the rates at which different fractions of DOM leak out of cells or are hydrolyzed from POM, as suggested by Westrich \& Berner (1984), Fuhrman (1987) and Biddanda (1988), experiments need to be performed on intact POM to more fully understand the dynamics of bacteria-POM-DOM interactions in natural systems. In this paper, I present results of a laboratory simulation of water column degradation of intact ${ }^{14} \mathrm{C}$-labelled phytoplankton designed to examine reaction kinetics during the long periods required to mineralize the cells.

\section{MATERIALS AND METHODS}

Approximately $2 \mathrm{I}$ of a ${ }^{14} \mathrm{C}$-labelled Skeletonema costatum culture was prepared by incubating an algal inoculum in Guillard \& Ryther's (1962) f/2 medium supplemented with $37 \mathrm{MBq}$ of $\mathrm{NaH}^{14} \mathrm{CO}_{3}$ for $2 \mathrm{wk}$ at $15^{\circ} \mathrm{C}$ under continuous light. This period should be adequate for uniform labelling of $S$. costatum cells according to Welschmeyer \& Lorenzen (1984). Then, $50 \mathrm{ml}$ aliquots of the culture were centrifuged at $10000 \mathrm{rpm}$ for $1 / 2 \mathrm{~h}$ to separate particulate $\left(\mathrm{PO}^{14} \mathrm{C}\right)$ from dissolved organic carbon $\left(\mathrm{DO}^{14} \mathrm{C}\right)$ and residual inorganic label $\left({ }^{14} \mathrm{CO}_{2}\right)$. The particulate algal fraction was washed into a flask with dialyzed seawater $k 1000$ molecular weight fraction of the same seawater used to prepare f/2 medium; Amicon DC10 unit used), and bubbled with carbon dioxide for $3 \mathrm{~h}$ followed by nitrogen for another $9 \mathrm{~h}$ to purge residual ${ }^{14} \mathrm{CO}_{2}$ and kill the algae. This stock suspension was stored at $2{ }^{\circ} \mathrm{C}$ in darkness under a nitrogen atmosphere until the experiment began $12 \mathrm{~h}$ later. Prior to use, less than $2 \%$ of the ${ }^{14} \mathrm{C}$ label in the stock suspension was found in the ${ }^{14} \mathrm{CO}_{2}$ fraction; the balance was in $\mathrm{PO}^{14} \mathrm{C}(76 \%)$, and $\mathrm{DO}^{14} \mathrm{C}$ that leaked out of the cells $(22 \%)$. The fate of algal culture $\mathrm{DO}{ }^{14} \mathrm{C}$ is examined in another paper (Pett unpubl.).

On Day 0 of the experiment (10 May 1987), $5 \mathrm{ml}$ portions of the ${ }^{14} \mathrm{C}$-labelled algal suspension, consisting of ca $40 \mu \mathrm{mol}$ of POC and $5.4 \times 10^{6} \mathrm{dpm}$, were added to 98 plastic bottles containing $250 \mathrm{ml}$ of seawater taken the previous day from a depth of $35 \mathrm{~m}$ at a central station in Bedford Basin, Nova Scotia, Canada (70 $\mathrm{m}$ maximum depth). The quantity added was chosen on the basis of total POC concentrations normally observed at the time of sample collection, near the end of the spring bloom (Parrish 1987). Sodium azide at a final concentration of $15 \mathrm{mmol} \mathrm{l}^{-1}$ (Rosson et al. 1984) was added to half of the samples to inhibit respiration and gain further insight into the kinetics of DOC release and consumption. The samples were placed on a slowly-rotating plankton wheel $(2 \mathrm{rpm})$ or reciprocating table in a dark, $10^{\circ} \mathrm{C}$ cold-room for incubations of 0 , $3,6,9,12,18$, and $24 \mathrm{~h}$, and $2,4,8,16,30,60,90,120$, 150 , and $180 \mathrm{~d}$. At each interval, triplicate samples were taken for analysis of $\mathrm{PO}^{14} \mathrm{C}, \mathrm{DO}^{14} \mathrm{C},{ }^{14} \mathrm{CO}_{2}$, total POC, total DOC, and bacteria counts.

The fractionation of ${ }^{14} \mathrm{C}$ into $\mathrm{PO}^{14} \mathrm{C}, \mathrm{DO}^{14} \mathrm{C}$ and ${ }^{14} \mathrm{CO}_{2}$ employed methods similar to those outlined by Novitsky (1986). A $5 \mathrm{ml}$ portion from each bottle was added to $60 \mathrm{ml}$ serum bottles and sealed with a sleevestyle stopper fitted with a polypropylene cup containing a folded filter wick saturated with $0.15 \mathrm{ml}$ of $\beta$ phenethylamine. Then $0.1 \mathrm{ml}$ of $2 \mathrm{~N} \mathrm{HCl}$ was injected into the sample to liberate ${ }^{14} \mathrm{CO}_{2}$. After at least $1 \mathrm{~h}$ of gentle mixing, the filter wick was removed and assayed for radioactivity in a liquid scintillation counter. Preliminary experiments on the efficacy of ${ }^{14} \mathrm{CO}_{2}$ extraction indicated asymptotic levels were attained after 45 min. The remaining liquid was further acidified with $4.9 \mathrm{ml}$ of ice-cold $2 \mathrm{NHCl}$ and after ca $1 \mathrm{~h}$ of mixing, filtered through a Millipore GS $(0.22 \mu \mathrm{m})$ membrane filter to separate $\mathrm{DO}^{14} \mathrm{C}$ and $\mathrm{PO}^{14} \mathrm{C}$ fractions. The membrane filter was washed twice with $5 \mathrm{ml}$ of $1 \mathrm{~N} \mathrm{HCl}$, and dissolved in $1.5 \mathrm{ml}$ of methyl cellosolve prior to liquid scintillation counting.

Total pools of DOC and POC were determined from samples passing through, or retained on organic-free $\left(450^{\circ} \mathrm{C}\right.$ ashed), Whatman $\mathrm{GF} / \mathrm{F}$ glass fibre filters rather than the organic Millipore filters used in ${ }^{14} \mathrm{C}$-fractionation. DOC was measured by the UV-oxidation technique of Gershey et al. (1979), while POC was measured after high temperature combustion of the filters in a Leco furnace. Both techniques employed a nondispersive infra-red analyzer for detection of $\mathrm{CO}_{2}$.

Samples for bacteria counts were preserved with $2 \%$ filtered $(0.2 \mathrm{um})$ formaldehyde buffered with sodium borate, and stored in a refrigerator until counted. The samples were enumerated by epifluorescence microscopy following 2 min staining with prepared acridine orange $(0.01 \%$, Becton-Dickinson No. 4940$)$, filtration onto Sudan-B Black stained 0.2 um Nuclepore filters, and immediate mounting in Cargille Type A immersion oil on a glass slide (Schwinghamer 1988). At least 400 cells were enumerated on each filter.

\section{RESULTS AND DISCUSSION}

Over the short term, community metabolism appeared to be fuelled mainly by consumption of labile algal leachates that were present in the original inoculum (Fig. 1a, b). Approximately $58 \%$ of this DOM 

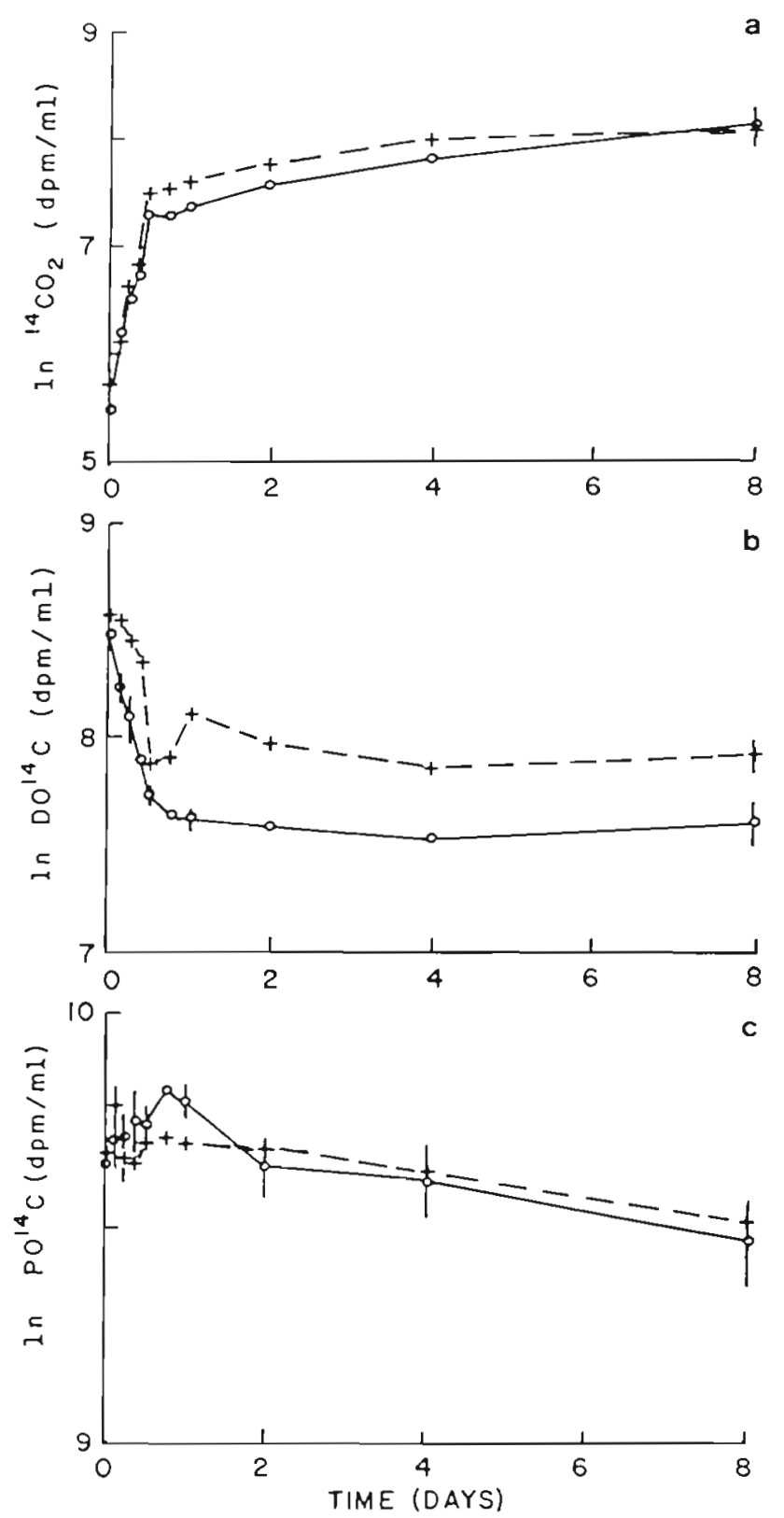

Fig. 1. Time-series measures of the natural log of (a) ${ }^{14} \mathrm{C}$ labelled carbon dioxide, (b) dissolved organic carbon, and (c) particulate organic carbon concentrations during early stages of mineralization of Skeletonema costatum. (o) Mean \pm 1 standard deviation of non-poisoned samples; $(+)$ mean \pm 1 standard deviation of sodium azide inhibited samples

leachate or $13 \%$ of added ${ }^{14} \mathrm{C}$, hereafter called $\mathrm{G}_{01}$ DOC, was consumed via first-order kinetics within $14 \mathrm{~h}$. Linearity of various portions in these plots verifies first-order consumption or production of organic pools, and the slopes give us the reaction rate constants (when natural logarithms are used). Uptake rates of $\mathrm{G}_{01}$-DOC that had leached out of the algae in the $24 \mathrm{~h}$ between centrifugation and sample amendment were calculated to be on the order of $0.06 \mathrm{~h}^{-1}\left(1.51 \mathrm{~d}^{-1}\right)$, comparable with the highly labile exudates released by living phytoplankton as observed by Lancelot (1979, 1984) and Pett (unpubl.). Approximately $50 \%$ of this material appeared to be directly metabolized to ${ }^{14} \mathrm{CO}_{2}$; the balance going into bacterial biomass (Fig. 1c). The remaining leachates were mineralized at rates 2 to 3 orders of magnitude slower (Table 1).

Table 1 A summary of first-order rate constants determined from time series measurements of ${ }^{14} \mathrm{C}$-labelled particulate and dissolved organic matter and carbon dioxide $\left(\mathrm{PO}^{14} \mathrm{C}, \mathrm{DO}{ }^{14} \mathrm{C}\right.$, ${ }^{14} \mathrm{CO}_{2}$, respectively) during mineralization of intact Skeletonema costatum cells in non-poisoned and sodium azide inhibited seawater samples. Positive values indicate production; negative values consumption. NS: rate constant not significantly different from zero

\begin{tabular}{|lcrrr|}
\hline \multirow{2}{*}{ Treatment } & Pool & \multicolumn{4}{c|}{ Rate constant $\left(\mathrm{d}^{-1}\right)$} \\
& & $\mathrm{PO}^{14} \mathrm{C}$ & ${ }^{14} \mathrm{CO}_{2}$ & $\mathrm{DO}^{14} \mathrm{C}$ \\
\hline Non-poisoned & $\mathrm{G}_{01}$ & 0.20 & 3.31 & -1.51 \\
& $\mathrm{G}_{02}$ & -0.08 & 0.10 & -0.01 \\
& $\mathrm{G}_{03}$ & -0.04 & 0.03 & $<-0.01$ \\
& $\mathrm{G}_{04}$ & -0.02 & $<0.01$ & - \\
Sodium azide & $\mathrm{G}_{01}$ & $\mathrm{NS}$ & 3.55 & -1.27 \\
inhibited & $\mathrm{G}_{02}$ & -0.05 & $\mathrm{NS}$ & 0.07 \\
& $\mathrm{G}_{03}$ & -0.01 & $\mathrm{NS}$ & 0.03 \\
& $\mathrm{G}_{04}$ & $\mathrm{NS}$ & $\mathrm{NS}$ & $\mathrm{NS}$ \\
\hline
\end{tabular}

Within 2 to $3 \mathrm{~d}$ of the removal of $\mathrm{G}_{01}$-DOC, bacterial numbers also rapidly declined from a high of $3 \times 10^{6}$ $\mathrm{ml}^{-1}$ at time zero to pre-addition levels of 0.5 to $1.0 \times$ $10^{6} \mathrm{ml}^{-1}$. As observed by Newell et al. (1981) and Biddanda \& Pomeroy (1988), this was also the time when numbers of protozoans became abundant. No further changes in bacterial density were observed over the following 6 mo.

The commonly-used sodium azide concentration of $15 \mathrm{mmol} \mathrm{l}^{-1}(0.1 \%$, e.g. Rosson et al. 1984) which was used here as a broad spectrum inhibitor of microbial metabolism, had little effect on bacterial respiration and only reduced uptake of $\mathrm{G}_{01}-\mathrm{DOC}$ by $11 \%$ in the first $8 \mathrm{~d}$ (Fig. 1a, b). As a result, the concentration was increased to $30 \mathrm{mmol}^{-1}$ on Day 10 and increased further by $10 \mathrm{mmol}^{-1}$ every $15 \mathrm{~d}$ or so until Day 90 , and then by $5 \mathrm{mmol} \mathrm{l}^{-1}$ until the end of the experiment. This stopped ${ }^{14} \mathrm{CO}_{2}$ production and caused $\mathrm{DO}^{14} \mathrm{C}$ to accumulate (Fig. 2). Higher starting concentrations of sodium azide ( 30 to $45 \mathrm{mmol}^{-1}$ ) in other experiments examining the uptake of algal culture $\mathrm{DO}^{14} \mathrm{C}$ (unpubl.) still did not completely eliminate uptake of $\mathrm{G}_{01}$-DOC. It should be noted however, that this fraction had already leaked out of the algae before sample amendment, and little metabolism of POM or DOM leachates occurred between the time of $\mathrm{G}_{01}$-DOC consumption and addition of more sodium azide. Unfortunately, this poor 

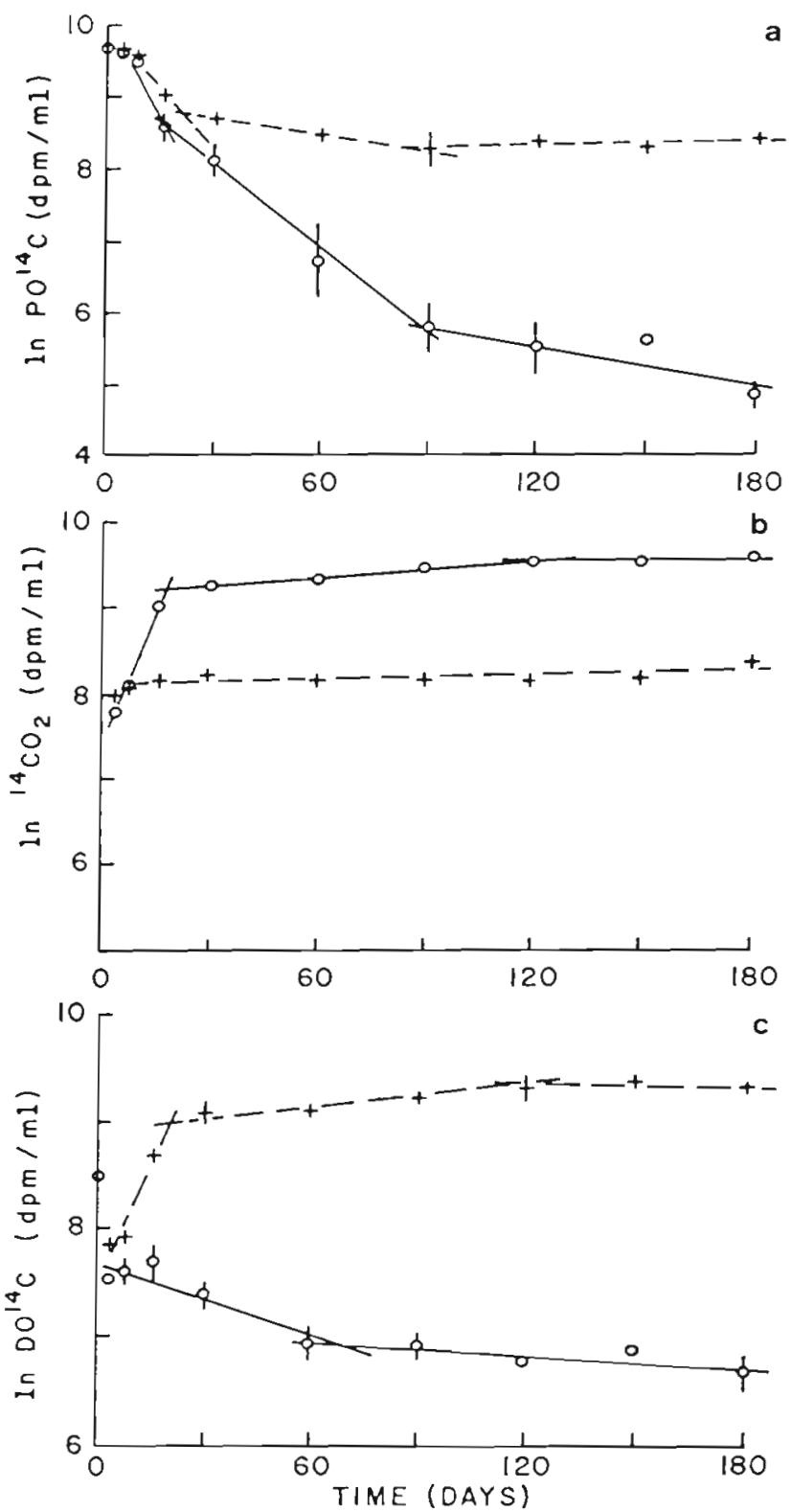

Fig. 2. Time-series measures of the natural $\log$ of $(a){ }^{14} \mathrm{C}$ labelled particulate organic carbon, (b) carbon dioxide, and (c) dissolved organic carbon concentrations during later stages of mineralization of Skeletonema costatum. Lines determined by linear least-squares regression analysis. (o) Mean \pm 1 standard deviation of non-poisoned samples; $(+)$ mean \pm 1 standard deviation of sodium azide inhibited samples

inhibition of DOC uptake by sodium azide amendment coupled with the possibilities that (1) the azide-inhibited bacteria may have altered the permeability of algal cell walls in the early part of the experiment and (2) enzymes released from azide-killed bacteria could be responsible for part of the DOC release from algae later on in the experiments, precludes an outright acceptance of the long-term $\mathrm{DO}^{14} \mathrm{C}$ accumulation rates as natural production rates of DOC from detrital algae.
Utilization of $\mathrm{PO}^{14} \mathrm{C}$ material was not evident until after ca Day 4 (Figs. 1c and 2a). Thereafter the longterm rates of ${ }^{14} \mathrm{CO}_{2}$ production (Fig. 2b) were very comparable to decay rates of $\mathrm{PO}^{14} \mathrm{C}$ (Table 1 ) and total POC. Total POC and $\mathrm{PO}^{14} \mathrm{C}$ behaved similarly throughout the experiment confirming uniform labelling of algal POM (correlation coefficient $=0.96, p<0.01$ ) The largest fraction of the algae, $\mathrm{G}_{02}$-type organic matter, comprising $54 \%$ of added ${ }^{14} \mathrm{C}$, was consumed in ca $17 \mathrm{~d}$ at a rate of $0.08 \mathrm{~d}^{-1}$. After this time, there was a distinct change in the slope of $\mathrm{PO}^{14} \mathrm{C}$ consumption and ${ }^{14} \mathrm{CO}_{2}$ production indicating another change in POM lability $\left(\mathrm{G}_{03}\right.$-organic matter, Fig. $2 \mathrm{a}$, b). Since $\mathrm{DO}^{14} \mathrm{C}$ was released at comparable rates in poisoned samples $\left(0.05 \mathrm{~d}^{-1}\right.$ calculated from data in Fig. 2c) and never accumulated in the non-poisoned samples, there appeared to be a tight coupling of POC breakdown and uptake of resultant DOC. Although subject to the limitations of sodium azide poisoning mentioned earlier, the $\mathrm{G}_{02}$-DOC was apparently consumed as fast as it leaked from the algae.

The remaining $23 \%$ of algal $\mathrm{PO}^{14} \mathrm{C}$, which was degraded from Day 17 to ca Day 90 at a rate of $0.04 \mathrm{~d}^{-1}$, also appeared to be mineralized as fast as $\mathrm{DO}^{14} \mathrm{C}$ accumulated in sodium azide inhibited samples, i.e. at $0.03 \mathrm{~d}^{-1}$ (Table 1). As a consequence of this 'apparent' tight coupling of $\mathrm{G}_{02}$ and $\mathrm{G}_{03}$-DOC production to community metabolism and POC breakdown, there was no significant change in the total DOC pool throughout the 6 mo experiment. $G_{03}$-particulate decay rates were nearly identical to mineralization rates for the more long-lived leachates in the original inoculum (and in experiments on the fate of culture exudates, Pett unpubl.), and are well within Ogura's (1972, 1975) estimates for his $F_{1}$ fraction of bulk seawater DOM and Westrich \& Berner's (1984) estimates for $\mathrm{G}_{01}$ plankton material.

After ca $90 \mathrm{~d}$, community metabolism and degradation rates of POM and DOM were again considerably reduced. All but $2 \%$ of the original algal $\mathrm{PO}^{14} \mathrm{C}$ and $16 \%$ of the $\mathrm{DO}^{14} \mathrm{C}$ leachate $\left(4 \%\right.$ of total added $\left.{ }^{14} \mathrm{C}\right)$ were consumed by the end of the experiment at rates of 1.8 and $0.7 \mathrm{yr}^{-1}$, respectively. Studies by Ogura (1972, 1975 ) and Westrich \& Berner (1984) on what I call $\mathrm{G}_{04}$ fractions of POC and DOC gave the same order of magnitude results: 0.4 to $1.1 \mathrm{Yr}^{-1}$.

Although this experiment only provides kinetic data for the mineralization of 1 algal species, on 1 occasion, it does help explain or clarify several recent controversies concerning bacteria-POM interactions and the fate of POM in the marine environment. In many coastal environments, where there is (1) more frequent mixing of the water column, (2) enhanced bacterial productivity arising from sediment resuspension (Wainright 1987), and (3) more abundant zooplankton populations 
than were present in my $250 \mathrm{ml}$ bottle samples, most of the $\mathrm{G}_{01}$ and $\mathrm{G}_{02}$-organic matter in sedimenting phytoplankton (67\% of Skeletonema costatum biomass). would leak out and probably be consumed in a matter of days or less, long before detrital algae finally settle onto the seabed. Rapid loss of large amounts of low molecular weight DOM after cell death is expected due to the large concentration gradient across phytoplankton cell walls (Bjørnsen 1988). Indeed this has been shown by several investigators in short-term experiments with the consequent development of bacteriaPOM aggregates (e.g. Newell et al. 1981, Garber 1984, Biddanda 1988).

Since most benthic and deep-water microbial communities are dependent upon POM settling out of surface waters, their response to 'fresh' inputs of POM will be related to nutritional status of both the POM and DOM after it has been subject to degradation in the water column. Depending upon the sinking rate, most of the $\mathrm{G}_{01}$ and $\mathrm{G}_{02}$-organic matter remaining in sinking particles (including bacteria themselves) would be rapidly recycled by particle fragmenters or be released into bulk seawater to subsequently enter the suspended matter microbial loop. Considering an average particle residence time of $30 \mathrm{~d}$ in the upper mixed layer of the oceans (Lande \& Wood 1987), sub-pycnocline microbial communities typically receive $\mathrm{G}_{03}$ and more resistant POM that has undergone considerable modification by zooplankton and bacteria (Altabet 1988, Wakeham \& Canuel 1988). Consequently, mineralization rates of sinking particulate matter and bacterioplankton growth rates decrease with increasing depth (Cho \& Azam 1988, Karl et al. 1988) and we often see little stimulation of benthic activity following sedimentation of algal blooms (Hargrave 1980, Czytrich et al. 1986, Kanneworff \& Christensen 1986, Rudnick \& Oviatt 1986). Clearly though, some relatively undegraded algae (or even living cells) do sink to the seabed very rapidly initiating an immediate, but short-lived pulse of benthic activity (Graf et al. 1983, Meyer-Reil 1983, Graf 1987a, b, Lochte \& Turley 1988).

Acknowledgements. This work was funded by grants from the Natural Sciences and Engineering Research Council of Canada (NSERC) to P. J. Wangersky. The author was supported by a NSERC Postgraduate Scholarship and a Dalhousie Graduate Fellowship. Special thanks to J. Grant, B. Johnson, P. Kepkay, J. Novitsky, P. Wangersky and 3 anonymous reviewers for very thorough criticism of this manuscript.

\section{LITERATURE CITED}

Altabet, M. A. (1988). Variations in nitrogen isotopic composition between sinking and suspended particles: implications for nitrogen cycling and particle transformation in the open ocean. Deep Sea Res. 35: 535-554
Azam, F. (1986). Nutrient cycling and food web dynamics in the Southern California Bight: the microbial food web. In: Eppley, R. W (ed.) Lecture notes on coastal and estuarine studies, Vol. 15. Plankton dynamics of the Southern California Bight. Springer-Verlag. New York, p. 275-288

Azam, F., Ammerman, J. W. (1984). Cycling of organic matter by bacterioplankton in pelagic marine ecosystems: microenvironmental considerations. In: Fasham, M. J. R. (ed.) Flows of energy and materials in marine ecosystems. Plenum Press, New York, p. 345-360

Azam, F., Cho, B. C. (1987). Bacterial utilization of organic matter in the sea. In: Fletcher, M., Gray, T R. G., Jones, J. G. (eds.) Ecology of microbial communities. Cambridge Univ. Press, Cambridge, p. 261-281

Berner, R. A. (1980). A rate model for organic matter decomposition during bacterial sulfate reduction in marine sediments. Colloq. Int. CNRS 293: 35-44

Biddanda, B. A. (1988). Microbial aggregation and degradation of phytoplankton-derived detritus in seawater. II. Microbial metabolism. Mar. Ecol. Prog. Ser. 42: 89-95

Biddanda, B. A., Pomeroy, L. R. (1988). Microbial aggregation and degradation of phytoplankton-derived detritus in seawater I. Microbial succession. Mar, Ecol, Prog. Ser. 42: $79-88$

Bjørnsen, P. K. (1988). Phytoplankton exudation of organic matter: why do healthy cells do it? Limnol. Oceanogr. 33: 151-154

Cho, B. C., Azam, F. (1988). Major role of bacteria in biogeochemical fluxes in the ocean's interior. Nature, Lond. 332: $441-443$

Czytrich, H., Eversberg, U., Graf, G. (1986). Interaction between pelagial and benthal during autumn in Kiel Bight. II. Benthic activity and chemical composition of organic matter Ophelia 26: 123-133

Fuhrman, J. (1987). Close coupling between release and uptake of dissolved free amino acids in seawater studied by an isotope dilution approach. Mar. Ecol. Prog. Ser. 37: $45-72$

Garber, J. H. (1984). Laboratory study of nitrogen and phosphorus remineralization during the decomposition of coastal plankton and seston. Estuar. coast. Shelf Sci. 18: 685-702

Gershey, R. M., Mackinnon, M. D., Williams, P. J. LeB., Moore, R. M. (1979). Companison of three oxidation methods used for the analysis of the dissolved organic carbon in seawater. Mar. Chem. 7: 289-306

Graf, G. (1987a). Benthic energy flow during a simulated autumn bloom sedimentation. Mar. Ecol. Prog. Ser. 39: 23-29

Graf, G. (1987b). Benthic response to the annual sedimentation pattem. In: Rumohr, J., Walger, E., Zeitzschel, B. (eds.) Lecture notes on coastal and estuarine studies, Vol. 13. Seawater-sediment interactions in coastal waters. An interdisciplinary approach. Springer-Verlag, New York, p. $84-92$

Graf, G., Schulz, R., Peinert, R., Meyer-Reil, L.-A. (1983) Benthic response to sedimentation events during autumn to spring at a shallow-water station in the Western Kiel Bight: I. Analysis of processes on a community level. Mar. Biol. 77: 235-246

Grant, J., Hargrave, B. T. (1987). Benthic metabolism and the quality of sediment organic carbon. Biol. Oceanogr. 4: 243-264

Guillard, R. R. L., Ryther, J. H. (1962). Studies on marine planktonic diatoms I. Cyclotella nana Hustedt and Detonula confervaceae (Cleve) Gran. Can. J. Microbiol. 8: $229-239$ 
Hargrave, B. T (1980). Factors affecting the flux of organic matter to sediments of a marine bay. In: Tenore, K. R., Coull, B. C. (eds.) Marine benthic dynamics. Univ. South Carolina Press, Columbia, p. 243-263

Henrichs, S. M., Doyle, A. P. (1986). Decomposition of ${ }^{14} \mathrm{C}-$ labelled organic substances in marine sediments. Limnol. Oceanogr. 31: 765-778

Hollibaugh, J. T., Azam, F. (1983). Microbial degradation of dissolved proteins in seawater Limnol. Oceanogr. 28: $1104-1116$

Kanneworff, E., Christensen, H. (1986). Benthic community respiration in relation to sedimentation of phytoplankton in the Oresund. Ophelia 26: 269-284

Karl, D. M., Knauer, G. A., Martin, J. H. (1988). Downward flux of particulate organic matter in the ocean: a particle decomposition paradox. Nature, Lond. 332: 438-441

Kepkay, P. E., Andersen, F. O. (1985). Aerobic and anaerobic metabolism of a sediment enriched with Spartina detritus. Mar. Ecol. Prog. Ser. 21. 153-161

Lancelot, C. (1979). Gross excretion rates of natural marine phytoplankton and heterotrophic uptake of excreted products in the southern North Sea, as determined by shortterm kinetics. Mar. Ecol. Prog. Ser. 1: 179-186

Lancelot, C. (1984). Extracellular release of small and large molecules by phytoplankton in the Southern Bight of the North Sea. Estuar. coast. Shelf Sci. 18: 65-77

Lande, R., Wood, A. M. (1987). Suspension times of particles in the upper ocean. Deep Sea Res. 34:61-72

Lochte, K., Turley, C. M. (1988). Bacteria and cyanobacteria associated with phytodetritus in the deep sea. Nature, Lond. 333: 67-69

Meyer-Reil, L.-A. (1983). Benthic response to sedimentation events during autumn to spring at a shallow-water station in the Western Kiel Bight. II. Analysis of benthic bacterial populations. Mar Biol. 77: 247-256

Newell, R. C., Lucas, M. I., Linley, E. A. S. (1981). Rate of degradation and efficiency of conversion of phytoplankton debris by marine microorganisms. Mar. Ecol. Prog. Ser. 26: $123-136$

Novitsky, J. A. (1986). Degradation of dead microbial biomass in a marine sediment. Appl. environ. Microbiol. 52: 504-509

This article was presented by Dr M. R. Lewis, Halifax, Nova Scotia, Canada
Ogura, N. (1972). Rate and extent of decomposition of dissolved organic matter in surface seawater Mar. Biol. 13: $89-93$

Ogura, N. (1975). Further studies on decomposition of dissolved organic matter in coastal seawater. Mar. Biol. 31: $101-111$

Parrish, C. C. (1987). Time series of particulate and dissolved lipid classes during spring phytoplankton blooms in Bedford Basin, a marine inlet. Mar Ecol. Prog. Ser. 35 $129-139$

Rego, J. V., Billen, G., Fontigny, A., Somville, M. (1985). Free and attached proteolytic activity in water environments. Mar Ecol. Prog. Ser. 21: 245-249

Rosson, R. A., Tebo, B. M., Nealson, K. H. (1984). Use of poisons in determination of microbial manganese binding rates in seawater Appl. environ. Microbiol. 47: $740-745$

Rudnick, D. T., Oviatt, C. A. (1986). Seasonal lags between organic carbon deposition and mineralization in marine sediments. J. mar Sci. 44: 815-837

Schwinghamer, P. (1988). Influence of pollution along a natural gradient and in a mesocosm experiment on sediment microbial numbers and biomass. Mar. Ecol. Prog. Ser. 46: 193-197

Schwinghamer, P., Kepkay, P. (1987). Effects of experimental enrichment with Spartina detritus on sediment community biomass and metabolism. Biol. Oceanogr. 4: 289-322

Wainright, S. C. (1987). Stimulation of heterotrophic production by resuspended marine sediments. Science 238: $1710-1712$

Wakeham, S. G., Canuel, E. A. (1988). Organic geochemistry of particulate matter in the eastern tropical North Pacific Ocean: implications for particle dynamics. J. mar. Res. 46: 183-213

Welschmeyer, N. A., Lorenzen, C. J. (1984). Carbon-14 labeling of phytoplankton carbon and chlorophyll a carbon: determination of specific growth rates. Limnol. Oceanogr. 29: $135-145$

Westrich, J. T., Berner, R. A. (1984). The role of sedimentary organic matter in bacterial sulfate reduction: the $\mathrm{G}$ model tested. Limnol. Oceanogr. 29: 236-249

Manuscript received: July 14, 1988

Revised version accepted: November 25, 1988 